\title{
Barriers to women entrepreneurship. Different methods, different results?
}

\author{
Ana Tur-Porcar ${ }^{1} \cdot$ Alicia Mas-Tur ${ }^{1} \cdot$ José Antonio Belso $^{2}$
}

Published online: 28 April 2016

(C) Springer Science+Business Media Dordrecht 2016

\begin{abstract}
Building on research by Akehurst et al. (Serv Ind J 32:2489-2505, 2012), this study analysed internal and external factors in women entrepreneurship and linked these factors to the barriers that women face when starting businesses. To do so, two contrasting statistical techniques were used: PLS and QCA. After analysing results from each of these techniques, we observed that family duties and difficulties in obtaining financing (both internal and external) were the main factors related to barriers faced by women entrepreneurs.
\end{abstract}

Keywords Women entrepreneurship · Barriers · Partial least squares (PLS) - Qualitative comparative analysis (QCA)

\section{Introduction}

Recent decades have seen the development of a broad range of ideas, debates and proposals that analyse gender relationships as a means of understanding the economic, social, political and institutional reality (Eddleston and Powell 2008). Such approaches combine to form a new focus in the social sciences. Although this new focus fails to constitute a comprehensive theory, it implies profound changes by rejecting conventional paradigms on account of their bias in the concepts, categories and analytical framework they use (Ogbor 2000).

These criticisms of the hitherto dominant research approach have led to a surge in studies into women's business activity driven by the development in feminist economics. Other milestones include events such as the 1997 OECD Conference on Women

Ana Tur-Porcar

ana.tur@uv.es

1 Universitat de València, Valencia, Spain

2 Universidad Miguel Hernández, Elche, Spain 
Entrepreneurs in SMEs in Paris, which brought together a great number of women entrepreneurs from around the world and succeeded in attracting attention towards the potential, opportunities and barriers related to women's business activity (Iannello 1993).

The current research is built on the model proposed by Akehurst et al. (2012) who analysed external and internal factors related to women entrepreneurs. Akehurst et al. studied the external factors of business expansion and financing. Among the internal factors were demographic characteristics of age, marital status, motherhood (whether the woman has small children and how many), and the importance and influence of the family. Using a series of regressions, Akehurst et al. observed these independent variables to be related to motivation, barriers and success of women entrepreneurs. The present study built on the model proposed by Akehurst et al. by focusing on the principal barriers faced by women entrepreneurs (infrastructure/training and education barriers and gender barriers) (Akehurst et al. 2012).

The aim of this study was twofold: first, to use different statistical techniques (PLS and QCA) to test the results obtained by Akehurst et al. (2012), and second, to observe the difference in results yielded by these two techniques.

To achieve these objectives, the article has the following structure. The next section reviews the most recent theories on women entrepreneurship, and the education and training/infrastructure barriers and gender barriers faced by women. In the third section, the two methods (PLS and QCA) are compared theoretically to lay the foundation for practical comparison in the fourth section to observe differences between results. The final section presents the study's conclusions.

\section{Factors related to barriers to women entrepreneurship}

As previously mentioned, this study explored factors related to the two types of barriers to women entrepreneurship: external (business expansion and financing) and internal (demographic characteristics of age, marital status, motherhood-small children and number of small children-and importance and influence of the family).

Regarding business expansion, numerous authors have concluded that the majority of women prefer to create businesses that are small in terms of both revenue and employment (Carter and Rosa 1998; Cowling and Taylor 2001; Akehurst et al. 2012). This choice owes to two main causes: (1) women experience greater difficulty than men do in securing resources to finance their businesses and (2) women tend to have a greater lack of specific knowledge than men do to skilfully perform their business activities. As we can see, both reasons relate to discrimination against women in the labour market. Nevertheless, other studies (Herron and Robinson 1993; Rey-Martí et al. 2015) have demonstrated that business expansion also depends on business owners' motivation and on attitude and intention with respect to the future of the business. Along these lines, other studies (Fischer et al. 1993; Rosa et al. 1996; Du Rietz and Henrekson 2000) have reported that business size is also related to women business owners' motivations and attitudes towards expansion, which differ from those of male business owners. Thus, although gender differences in propensity for risk are not always present, women's propensity for risk generally seems lower than men's (Akehurst et al. 2012).

Building on this theoretical framework, we formulated and tested the following proposition: Business expansion is a barrier for woman entrepreneurs (H1). 
Access to financing is a challenge faced by many women because of the additional challenges they must overcome to secure resources (Hertz 2011). When starting businesses, women usually finance their ventures using funds from the family economy. Thus, the state of the family economy is important for women entrepreneurs. Nevertheless, as numerous studies have shown, a lack of capital in the early stages can negatively affect businesses in the long term. Researchers have demonstrated that less initial capital influences the business owner's capacity to achieve bank financing (Storey 1994). Likewise, other studies have shown that the percentage of women business owners who use their savings to fund business operations falls after the first year, whereas the percentage of women business owners who use bank loans increases after the first year (Welsh et al. 2014).

Another key aspect of financing is the fact that access to capital is a critical issue for the survival of SMEs. Without sufficient financial resources, business owners cannot develop new products and services, commit to expansion plans, create jobs, or perform a host of other actions. Along these lines, certain authors have concluded that the ease of access to financing is related to whether the business is created and run by a woman. Several studies have demonstrated that women have to secure financing under less favourable conditions than men do (Pellegrino and Reece 1982; Coleman 2000). Similarly, other authors have concluded that women entrepreneurs encounter greater difficulties than men do in accessing the financial resources necessary to start a business activity and that women encounter problems of credibility when dealing with financial institutions (Orhan 2001; Verheul and Thurik 2001).

In accordance with this theoretical and empirical basis, we formulated and tested the following proposition: The difficulty in accessing financing is a barrier for woman entrepreneurs $(H 2)$.

We now examine demographic characteristics of women such as age, marital status, having small children and the number of small children. There does not seem to be a direct relationship between age and an increase in business difficulties, as reported by Bates (2002) and Lerner and Almor (2002). Most women entrepreneurs begin their business projects aged between 36 and 45, although many women also start businesses aged between 26 and 35 . The fact that the majority of women are 36 or older could be influenced by their status as mothers (i.e., whether they have children and how many children they have) (Yilmaz and Oraman 2012).

In contrast, scholars have reported a relationship between women business owners' marital status and their business activity (DeMartino and Barbato 2003; Hinz 2004). Women seek a balance between work needs and the needs of raising a family (Morris et al. 2006). Results indicate that having a family does not hinder business creation among women (Ronsen 2014). As Carter and Rosa (1998) reported, however, women business owners are more successful when they do not seek to mix family with business.

With respect to children, the literature is ambiguous: some authors have reported a relationship between business activity and having young children (Carter and Rosa 1998), whereas other authors have reported that children negatively influence job creation and therefore the expansion of women's businesses Brush (1992), Brush et al. (2003); Kevane and Wydick 2001).

Based on this conceptual framework, we formulated and tested the following proposition: Women entrepreneurs' demographic characteristics are a barrier for them (H3).

The influence of the family can also affect business creation by women. Support from the family towards women is a key factor in business success (Steier et al. 2009). Family support positively affects business performance. Conversely, family problems negatively 
affect business performance. Bruce (1999) reported that the probability that a woman becomes a business owner if her husband also owns a business is twice the probability if the husband does not own a business. Similarly, Hisrich and Brush (1983) observed that nearly $50 \%$ of women entrepreneurs' fathers own businesses.

Consistent with this theoretical framework, we formulated and tested the following proposition: Women business owners' family ties influence the barriers they face (H4).

\section{Methodology: PLS \& QCA}

This research employed two methodologies: one quantitative, namely partial least squares (PLS), and the other qualitative, namely qualitative comparative analysis (QCA) in its fuzzy-set form (fsQCA).

\subsection{Partial least squares-PLS}

Partial least squares (PLS) is an extension of principle component analysis (PCA) (Wold et al. 1983). Both methods follow the principal known as soft modelling, which means analysis of models based on empirical data rather than theoretical or logical constructions, as is the case in hard modelling (Sundbom 1992). Therefore, PLS can be used to clarify complex patterns in the data.

The aim of PCA is to find inherent structure in a dataset. All variables in the datasets are processed simultaneously and are then ordered to find variables with the highest loading. The variables that supply little information are dropped. These new information-carrying components are called principle components (Henningsson et al. 2001).

PLS is a statistical data analysis method built on multivariate regression. PLS uses the projection of latent variables to reduce strongly correlated dimensional data into a much smaller dataset that can thus be interpreted (Bang et al. 2002). This method's objective is to predict the dependent variable (Cepeda and Roldán 2004). The original PLS algorithm was developed as a linear regression method using an internal linear relation in the latent space (Bang et al. 2002). According to Chin et al. (2003), PLS is the most suitable method to perform predictive studies.

According to Bang et al. (1998), PLS is a multivariate linear regression algorithm that can handle correlated inputs and limited data. The algorithm reduces the dimension of the input variables (input matrix, $X$ ) into the lower-dimension response variables (output matrix, $Y$ ) via projections in the directions (input and output of weight $w$ weight $c$ ) that maximize the covariance between the input and output variables.

This projection method is decomposed into variables of high collinearity and unidimensional variables. A small number of principle components is calculated. The main difference with other methods is that this process is carried out for both matrix $X$ and matrix $Y$, and the relationship between these two datasets is maximized. Testing is carried out using cross-validation (goodness of prediction, or value $Q^{2}$ ). The value $Q^{2}$ is a measure of the model's predictive capability. A value greater than 0.1 implies significant predictive power in the model. The $R^{2}$ values explain the variance or "goodness of fit" of the model. Adding more components to a model can increase the explained variance (Henningsson et al. 2001).

The PLS method is used in a variety of areas where multivariate data emerge both in theoretical research and in reality (Bang et al. 1998). This method was designed to reflect 
the theoretical and empirical conditions of social sciences and behaviour, where it is common to encounter situations with little theoretical grounding and scarce information (Wold 1979).

\subsection{Qualitative comparative analysis-QCA}

QCA is a set-theoretical method that assumes that the influence of certain elements on a specific outcome depends on combinations of these elements rather than the prevalence of the individual elements per se (Ragin 2008). This method uses Boolean algebra to identify which combinations of properties are sufficient and/or necessary conditions to produce an outcome of interest (Fiss 2007). "QCA performs a systematic cross-case analysis that models relations among variables in terms of set membership" (Ordanini et al. 2013).

Consequently, this technique is both qualitative and quantitative (i.e., hybrid), and it is gaining popularity among researchers, particularly in topics related to business management (Fiss 2007; Greckhamer et al. 2008) and innovation (Ordanini and Maglio 2009). According to Berg-Schlosser (2008), The QCA model can address five possible objectives: (1) summarizing data, (2) checking data coherence, (3) testing hypotheses and existing theories, (4) analysing basic assumptions, and (5) developing new theoretical arguments.

The specific requirements of QCA correspond to research questions-case selection and variable specification-and the calibration of conditions (Ragin 2000). This method specifically captures the idea of equifinality (Fiss, 2007). The application of QCA follows four steps (Fiss 2011): (1) defining the property space, (2) developing the measures and determining the thresholds for degree of membership, (3) evaluating the coherence of the set-membership relationships and (4) reducing the solution using algorithms.

The technique, which is based on Boolean logic, was originally developed by Ragin (1987). In QCA, explanatory factors ("conditions") and the explained phenomenon ("outcome") are classified in two groups. This was later termed "crisp-set" QCA (csQCA), which consists of dichotomously categorizing whether cases are "completely in" $\{1\}$ or "completely outside" $\{0\}$ a set. Later, however, Ragin developed an alternative "fuzzy-set" technique (fsQCA), which does not attempt to force-fit cases into one of the two discrete categories, but instead assigns a score in the interval $\{0,1\}$ corresponding to degree of membership in the set. In short, there are basically two specific QCA methods: crisp-set qualitative comparative analysis (csQCA) and fuzzy-set qualitative comparative analysis (fsQCA). CsQCA suits the study of variables with binary values ( 0 or 1$)$. The value 1 indicates the presence of a particular characteristic, whereas 0 indicates its absence. For variables that take ordinal or continuous values, however, fsQCA is more suitable.

The dichotomous form of QCA, namely crisp-set QCA (csQCA), is a classic settheoretic QCA approach that permits direct comparison using standard statistical techniques to handle variables that are treated as dichotomous. CsQCA allows researchers to better compare and contrast the uses and theoretical objectives of QCA with those of more traditional methods (Grofman and Schneider 2009). Fuzzy-set (fsQCA), in contrast, expresses links between different combinations of causal conditions and outcomes as necessary and/or sufficient. 
Table 1 Comparison between PLS and QCA (based on Cepeda and Roldán 2004)

\begin{tabular}{|c|c|}
\hline Partial least squares (PLS) & Qualitative comparative analysis (QCA) \\
\hline Partial least squares analysis & Qualitative comparative analysis \\
\hline $\begin{array}{l}\text { Data are necessarily reduced, which leads to a loss of } \\
\text { data }\end{array}$ & Data reduction guided by theory \\
\hline $\begin{array}{l}\text { Variables with very little information are dropped/ } \\
\text { Finds variables with the highest loadings/Tackles } \\
\text { collinear variables }\end{array}$ & Handling of multiple conjunctures \\
\hline $\begin{array}{l}\text { Handling of binary dependent and independent } \\
\text { variables resulting from open questions }\end{array}$ & $\begin{array}{l}\text { Handling of binary dependent and independent } \\
\text { variables resulting from open questions }\end{array}$ \\
\hline Multivariate method/Univariate method & Slow yet versatile methods \\
\hline $\begin{array}{l}\text { Objective to find the inherent structure of a data set, } \\
\text { soft modelling }\end{array}$ & $\begin{array}{l}\text { Objective of searching for similarities and } \\
\text { differences within a group }\end{array}$ \\
\hline $\begin{array}{l}\text { Analyses models based on empirical data and not } \\
\text { theoretical or logical constructions }\end{array}$ & $\begin{array}{l}\text { Aims to capture a common phenomenon defined by } \\
\text { the study objective }\end{array}$ \\
\hline $\begin{array}{l}\text { Smaller number of subjects and a greater number of } \\
\text { variables }\end{array}$ & $\begin{array}{l}\text { Small number of subjects and a greater number of } \\
\text { variables }\end{array}$ \\
\hline $\begin{array}{l}\text { Can capture contextual influences more easily than } \\
\text { QCA can }\end{array}$ & $\begin{array}{l}\text { There exist two specific QCA methods: crisp-set } \\
\text { QCA (dichotomous variables) and fuzzy-set QCA } \\
\text { (continuous variables) }\end{array}$ \\
\hline Data are projected on planes or hyperplanes & Dependent variable is known as 'outcome' \\
\hline Used to clarify complex patterns & \\
\hline
\end{tabular}

Table 1 summarizes the principle characteristics of PLS and QCA. This comparison is based on research by Barroso et al. (2005), Cepeda and Roldán (2004), Ragin (2008), Woodside and Zhang (2013), and Schneider and Wagemann (2012).

\subsection{Model and variables}

We operationalized the study variables and adapted Akehurst et al.'s (2012) model as a reference for subsequent validation and hypothesis testing with PLS and fsQCA. Table 2 displays the dependent and independent variables (PLS) - or conditions and outcomes, as they should be referred to when working with fsQCA. Theoretical justification for the variable description appears in the supporting literature column, which cites research that supports the inclusion of these variables (or conditions) in the models.

To perform this study, we used a database of women entrepreneurs from the region of Valencia (Spain) who created businesses between 2010 and $2012(\mathrm{n}=155)$. The information was obtained through surveys carried out in person with the women business owners. The design of the questions was primarily based on studies that had already been tested, including amongst others, those carried out by Verheul and Thurik (2001), Ribeiro (2003a, b), Carter et al. (2007).

Figure 1 shows the model analysed using PLS and fsQCA methodologies.

We analysed the internal reliability of the scales in each dimension using Cronbach's (1951) alpha. Nunnally (1978) showed that this coefficient should be greater than or equal to 0.7 to confirm a scale's reliability. In this study, all values of Cronbach's alpha were 
Table 2 Variable definitions

\begin{tabular}{|c|c|c|c|}
\hline Label & Variable & Description & Supporting literature \\
\hline EXP & $\begin{array}{l}\text { Business } \\
\text { expansion }\end{array}$ & $\begin{array}{l}\text { Business size the entrepreneur hoped to } \\
\text { achieve in the near future (within } \\
3 \text { years) }\end{array}$ & $\begin{array}{l}\text { Hisrich and Brush (1983), Carter } \\
\text { and Rosa (1998), Herron and } \\
\text { Robinson (1993), Fischer et al. } \\
\text { (1993), Rosa et al. (1996), Du } \\
\text { Rietz and Henrekson (2000), } \\
\text { Cowling and Taylor (2001), } \\
\text { Akehurst et al. (2012) }\end{array}$ \\
\hline IF & Internal financing & $\begin{array}{l}\text { Access to financing from own resources } \\
\text { or from loans from family and friends }\end{array}$ & \multirow{2}{*}{$\begin{array}{l}\text { Pellegrino and Reece (1982), } \\
\text { Storey (1994), Coleman (2000), } \\
\text { Orhan (2001), Verheul and } \\
\text { Thurik (2001), Hertz (2011), } \\
\text { Welsh et al. (2014) }\end{array}$} \\
\hline EF & $\begin{array}{l}\text { External } \\
\text { financing }\end{array}$ & $\begin{array}{l}\text { Access to bank financing, venture capital, } \\
\text { public aids or subsidies and commercial } \\
\text { loans }\end{array}$ & \\
\hline AGE & Age & Age when the business was created & $\begin{array}{l}\text { Bates (2002), Lerner and Almor } \\
\text { (2002), Yilmaz and Oraman } \\
\text { (2012), Martí et al. (2014) }\end{array}$ \\
\hline CHIL & Family/children & $\begin{array}{l}\text { Number of children when the business } \\
\text { was created }\end{array}$ & $\begin{array}{l}\text { Carter and Rosa (1998), Brush } \\
\text { (1992, 2003), Kevane and } \\
\text { Wydick (2001), DeMartino and } \\
\text { Barbato (2003), Hinz (2004), } \\
\text { Morris et al. (2006), Ronsen } \\
\text { (2014) }\end{array}$ \\
\hline STA & Marital status & $\begin{array}{l}\text { Marital status when the business was } \\
\text { created }\end{array}$ & $\begin{array}{l}\text { Carter and Rosa (1998), Brush } \\
\text { (1992, 2003), Kevane and } \\
\text { Wydick (2001), DeMartino and } \\
\text { Barbato (2003), Hinz (2004), } \\
\text { Morris et al. (2006), Ronsen } \\
\text { (2014) }\end{array}$ \\
\hline $\begin{array}{l}\text { FAM/ } \\
\text { FRI }\end{array}$ & Family support & $\begin{array}{l}\text { Support received from the family } \\
\text { environment when the business was } \\
\text { created }\end{array}$ & $\begin{array}{l}\text { Hisrich and Brush (1983), Bruce } \\
\text { (1999), Steier et al. (2009) }\end{array}$ \\
\hline GEN & Gender barriers & $\begin{array}{l}\text { Set of three questions from the } \\
\text { questionnaire: women encounter } \\
\text { greater difficulty than men do to create } \\
\text { businesses; women receive less support } \\
\text { from society than men do to create } \\
\text { businesses; gender discrimination }\end{array}$ & \multirow{2}{*}{$\begin{array}{l}\text { Hisrich and Brush (1983), Carter } \\
\text { and Rosa (1998), Cooper } \\
\text { (1993), Herron and Robinson } \\
\text { (1993), Fischer et al. (1993), } \\
\text { Rosa et al. (1996), Du Rietz and } \\
\text { Henrekson (2000), Cowling and } \\
\text { Taylor (2001), Orhan (2001), } \\
\text { Verheul and Thurik (2001), } \\
\text { DeMartino and Barbato (2003), } \\
\text { Hinz (2004), Morris et al. } \\
\text { (2006), Hertz (2011), Akehurst } \\
\text { et al. (2012), Huarng et al. } \\
\text { (2012), Welsh et al. (2014), } \\
\text { Rey-Martí et al. (2015), Ronsen } \\
\text { (2014) }\end{array}$} \\
\hline INFR & $\begin{array}{l}\text { Training and } \\
\text { education/ } \\
\text { infrastructure } \\
\text { barriers }\end{array}$ & $\begin{array}{l}\text { Set of six questions from the } \\
\text { questionnaire: lack of advice and } \\
\text { information about the business activity; } \\
\text { deficient transport and communication; } \\
\text { lack of business training; problems to } \\
\text { balance business activities with family } \\
\text { duties; lack of contact with business } \\
\text { institutions; lack of business role } \\
\text { models }\end{array}$ & \\
\hline
\end{tabular}




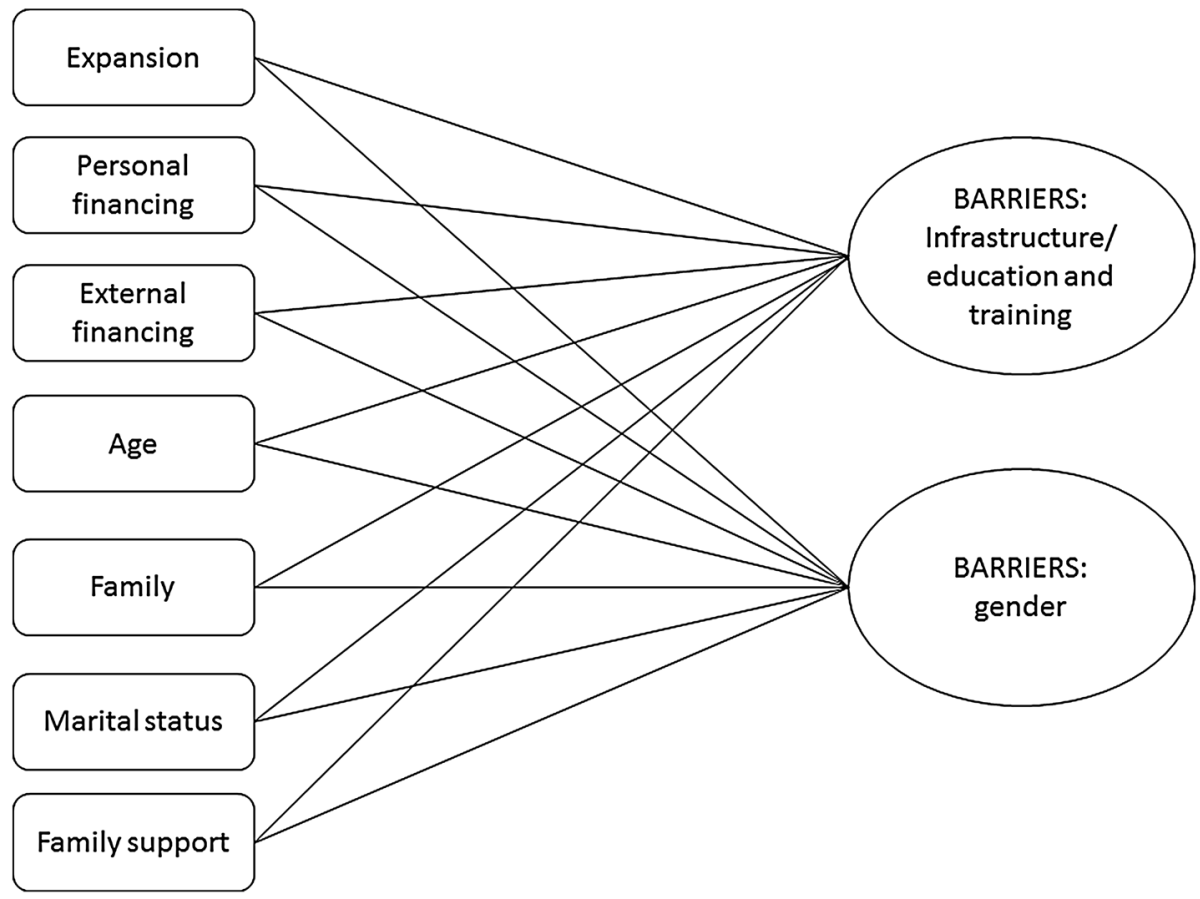

Fig. 1 Theoretical model

greater than 0.78. Next, as per Akehurst et al.'s (2012) study, we performed factor analysis to identify principle factors and thus reduce dimensions in the model.

In the following paragraph, we will do a PLS analysis and a QCA analysis to test the results that were obtained using regression analysis.

\section{Results}

\subsection{Partial least squares (PLS)}

\subsubsection{Results}

Using SIMCA - T + by Umetrics (2008), we obtained the following results. First, the variance in the dependent variable in both models (infrastructure/training and education barriers and gender barriers) was $90 \%$, with a very similar predictive power. Independent variables were almost completely explained $(90 \%)$.

Figure 2 shows the variables ( $x$ 's and $y$ 's) in the PLS components. The closer the $x$ variables are to the $y$ variables, the greater the positive effect of these variables. If the $x$ variables appear in a different quadrant from the $y$ variables, then they are negatively related (in the corresponding component). Therefore, in this study, all variables were positively related, except external financing. 


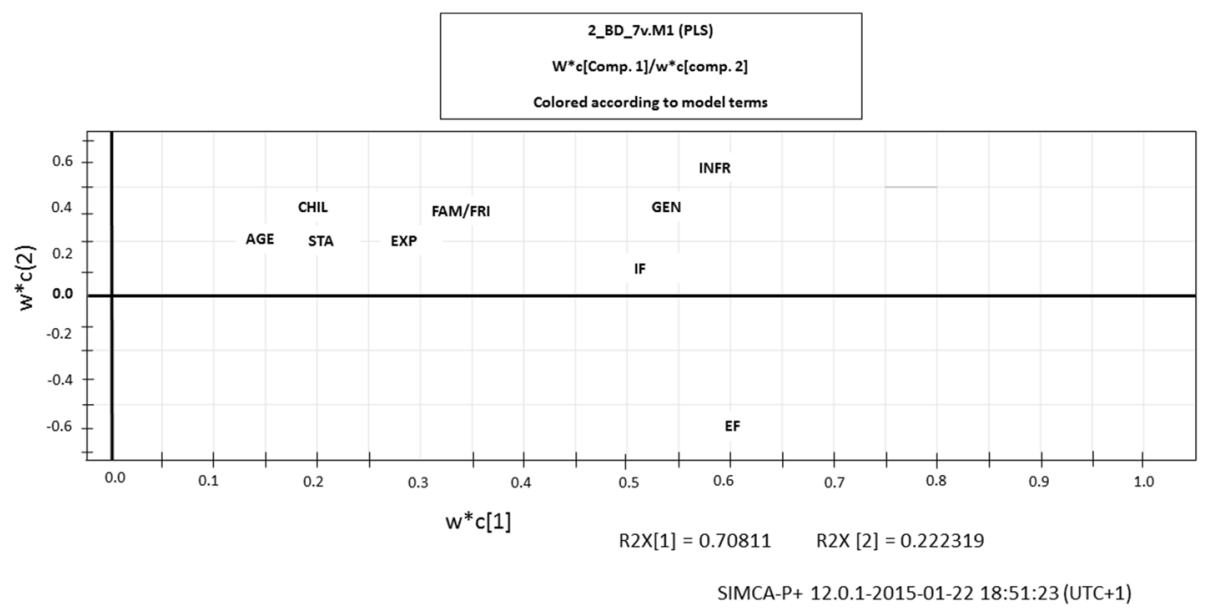

Fig. 2 PLS coefficients

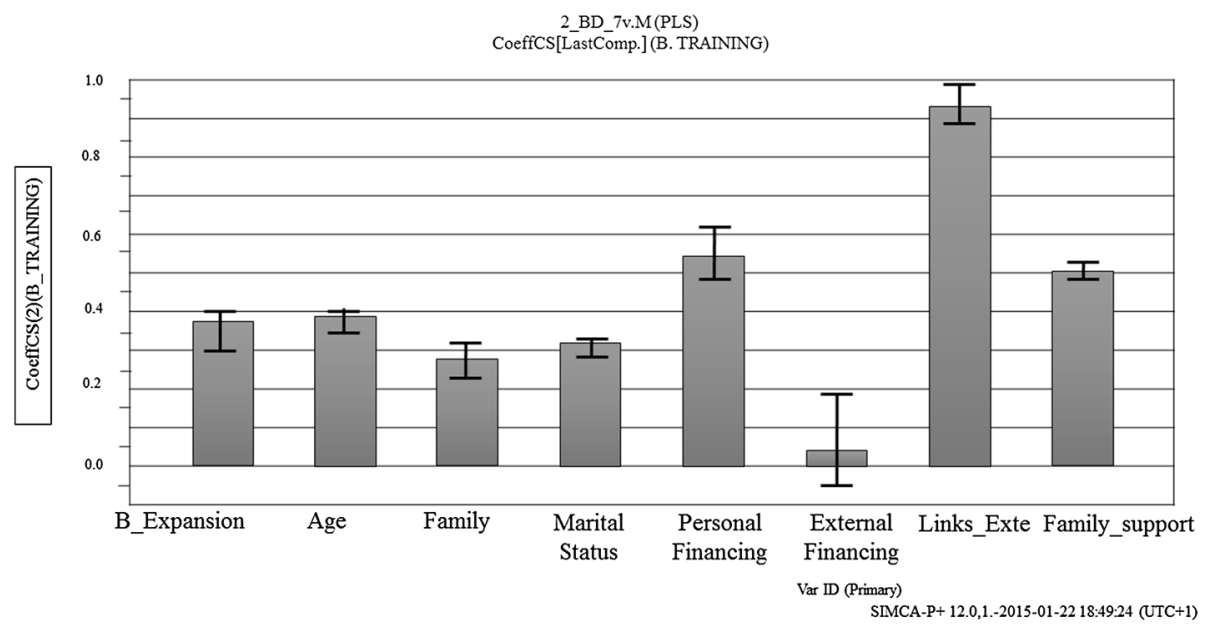

Fig. 3 PLS variances

Examination of the coefficient graphs (Figs. 3, 4) yielded the same conclusions as for Fig. 2.

These graphs show that all variables positively affect the existence of barriers-both gender barriers and education and training/infrastructure barriers-because the confidence intervals do not include 0 . The variable capturing access to external financing, which in Image 3 seems to negatively affect the existence of barriers, ultimately exerts a very small positive effect. In other words, for the external factors, both business expansion and women entrepreneurs' difficulties in obtaining financing (be it internal or external financing) increase the barriers to women entrepreneurship. As regards internal factors, age, being married and having a family increase difficulties for women entrepreneurs. Notably, however, support from family and friends acts as a barrier to women entrepreneurship. 


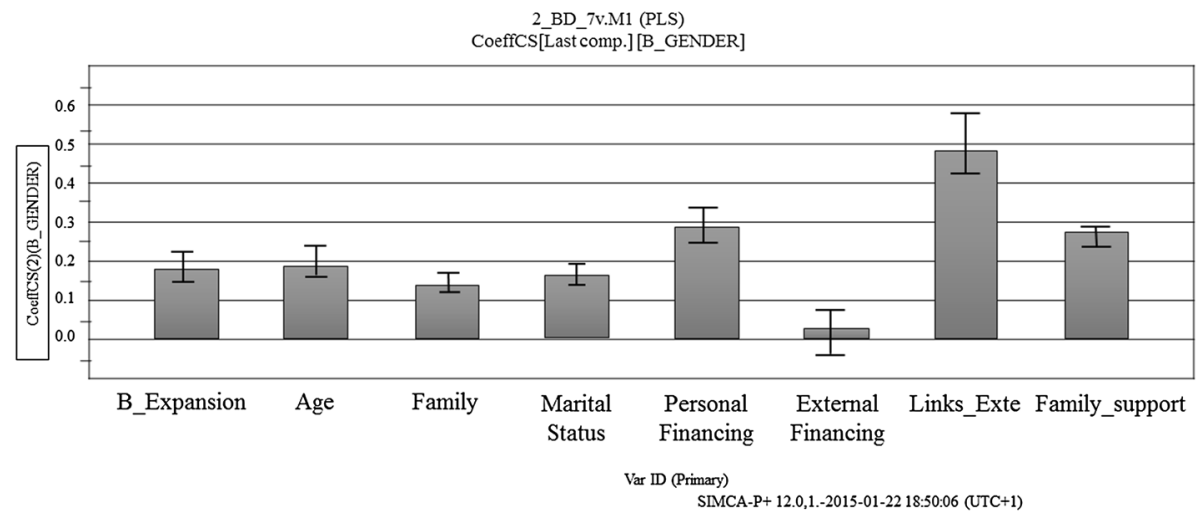

Fig. 4 PLS variances

\subsection{Fuzzy-set qualitative comparative analysis (fsQCA)}

\subsubsection{Calibration}

Following Ragin's (2008) recommendations, the first step when working with fsQCA was to calibrate the data. Calibration in fsQCA consists of establishing levels to represent degrees of membership to the group. Specifically, the degree of membership ranges from 0 to 1 , with 0 representing non-membership and 1 representing complete membership (Ragin 2008). In this research, we used fsQCA 2.5 software (Ragin and Davey 2014) to perform the direct calibration method, as proposed by Ragin (2008). This method requires users to establish the thresholds for non-membership (0), maximum ambiguity/crossover point (0.5) and total membership (1).

To establish these three thresholds, we followed the recommendations proposed by Ragin (2008), Rihoux and Ragin (2009), Crilly et al. (2012), Schneider and Wagemann (2012), Woodside and Zhang (2013).

Table 3 shows the thresholds established for each condition and for the outcomes. Owing to the nature of the conditions FAM and STA, we established the calibration as 0 (full nonmembership) or 1 (full membership). In addition, the variable FAM was subdivided into two variables to allow us to perform the analysis correctly, giving rise to the variable FAM (family support) and the variable FRI (support from friends and acquaintances).

\subsubsection{Results of $f$ s $Q C A$}

First, we performed an analysis of necessary conditions for the outcomes of training and education/infrastructure barriers and gender barriers. To imply that a condition is necessary, consistency must be greater than 0.9 (Ragin 2008; Schneider et al. 2010).

First, Table 4 shows that having children (0.98) is the only condition with a consistency greater than 0.90 for both training barriers and gender barriers. Second, demographic characteristics (age + family + marital status), with a consistency of 0.98 for both types of barriers, constitute a necessary condition. Third, the conditions of financing (internal + external) yield values of 0.92 and 0.93 for the training and gender barriers, respectively, and are also found to be barriers to women entrepreneurs. 
Table 3 Fuzzy-set scores

\begin{tabular}{llll}
\hline Variables & 0.05 (full non-membership) & 0.5 (crossover point) & 0.95 (full membership) \\
\hline EXP & 1.5 & 3.5 & 4.5 \\
AGE & 1.5 & 3.5 & 4.5 \\
IF & 1 & 7.1 & 14.80 \\
EF & 0.7 & 8.1 & 13.2 \\
FAM & 1.5 & 2.5 & 4.5 \\
FRI & 6 & 8.1 & 10 \\
INFR & 9.36 & 17.1 & 26 \\
GEN & 5.0 & 9.1 & 13.64 \\
\hline & & 0 (full non-membership) & 1 (full membership) \\
\hline CHIL & & No children & Has children \\
STA & & Not in a stable relationship & In a stable relationship \\
\hline
\end{tabular}

Table 4 Necessary conditions

\begin{tabular}{|c|c|c|c|c|}
\hline \multirow[t]{2}{*}{ Conditions } & \multicolumn{2}{|l|}{ INFR } & \multicolumn{2}{|l|}{ GEN } \\
\hline & Consistency & Coverage & Consistency & Coverage \\
\hline EXP & 0.629910 & 0.741536 & 0.624407 & 0.738563 \\
\hline$\sim \mathrm{EXP}$ & 0.727553 & 0.644624 & 0.737783 & 0.656805 \\
\hline AGE & 0.793631 & 0.619470 & 0.799497 & 0.627026 \\
\hline$\sim \mathrm{AGE}$ & 0.554012 & 0.794887 & 0.543843 & 0.784018 \\
\hline CHIL & 0.986111 & 0.502071 & 0.986177 & 0.504500 \\
\hline$\sim \mathrm{CHIL}$ & 0.013889 & 0.990000 & 0.013823 & 0.990000 \\
\hline STA & 0.626824 & 0.502022 & 0.634460 & 0.510562 \\
\hline$\sim$ STA & 0.373176 & 0.511538 & 0.365540 & 0.503462 \\
\hline FAM & 0.877946 & 0.574814 & 0.890115 & 0.585561 \\
\hline$\sim$ FAM & 0.335017 & 0.743231 & 0.329936 & 0.735450 \\
\hline IF & 0.701880 & 0.642481 & 0.675789 & 0.621549 \\
\hline$\sim \mathrm{IF}$ & 0.496352 & 0.560431 & 0.536163 & 0.608269 \\
\hline $\mathrm{EF}$ & 0.798260 & 0.584609 & 0.823234 & 0.605774 \\
\hline$\sim \mathrm{EF}$ & 0.347643 & 0.567438 & 0.321977 & 0.528051 \\
\hline FRI & 0.676347 & 0.628553 & 0.671740 & 0.627249 \\
\hline$\sim \mathrm{FRI}$ & 0.575898 & 0.638414 & 0.571628 & 0.636703 \\
\hline $\mathrm{AGE}+\mathrm{CHIL}+\mathrm{STA}$ & 0.986111 & 0.502071 & 0.986177 & 0.504500 \\
\hline $\mathrm{IF}+\mathrm{EF}$ & 0.929153 & 0.584864 & 0.936750 & 0.592458 \\
\hline
\end{tabular}

" " indicates absence of the condition and "+" indicates OR

Next, we performed the analysis of sufficient conditions. To obtain causal conditions sufficient to produce the outcome, we computed the truth table with $256\left(2^{8}\right)$ combinations, establishing a consistency cut-off of 0.800167 and 0.804062 for training and gender barriers, respectively. 
Table 5 Intermediate solution for training barriers

\begin{tabular}{|c|c|c|c|}
\hline Intermediate solution for training barriers & Raw coverage & Unique coverage & Consistency \\
\hline $\mathrm{EF}^{*} \mathrm{CHIL}^{*} \sim \mathrm{AGE}^{*} \sim \mathrm{EXP}$ & 0.453002 & 0.027778 & 0.853330 \\
\hline $\mathrm{EF}^{*} \mathrm{IF}^{*} \mathrm{STA}^{*} \mathrm{CHIL}$ & 0.391695 & 0.099186 & 0.698000 \\
\hline$\sim \mathrm{EF}^{*} \mathrm{IF}^{*} \sim \mathrm{STA}^{*} \sim \mathrm{AGE}^{*} \sim \mathrm{EXP}$ & 0.076038 & 0.008417 & 0.887070 \\
\hline$\sim \mathrm{FRI}^{*} \sim \mathrm{STA}^{*} \mathrm{CHIL}^{*} \sim \mathrm{AGE}^{*} \sim \mathrm{EXP}$ & 0.119248 & 0.003507 & 0.742358 \\
\hline$\sim \mathrm{FRI}^{*} \mathrm{EF}^{*} \mathrm{IF}^{*} \mathrm{CHIL} * \sim \mathrm{AGE}$ & 0.297138 & 0.010382 & 0.878838 \\
\hline$\sim \mathrm{EF}^{*} \mathrm{IF}^{*} \sim \mathrm{STA}^{*} \mathrm{CHIL} * \mathrm{AGE}$ & 0.085297 & 0.005752 & 0.840941 \\
\hline$\sim \mathrm{EF} * \mathrm{IF}^{*} \mathrm{CHIL} * \mathrm{AGE} * \mathrm{EXP}$ & 0.224748 & 0.021465 & 0.845382 \\
\hline $\mathrm{FRI}^{*} \mathrm{EF}^{*} \sim \mathrm{IF}^{*} \sim \mathrm{STA}^{*} \mathrm{CHIL}^{*} \sim \mathrm{EXP}$ & 0.149691 & 0.027076 & 0.817625 \\
\hline FRI*EF*STA*CHIL*AGE*EXP & 0.239057 & 0.016554 & 0.851149 \\
\hline$\sim \mathrm{FRI}^{*} \mathrm{EF}^{*} \sim \mathrm{IF}^{*} \sim \mathrm{STA}^{*} \mathrm{CHIL}^{*} \mathrm{AGE}^{*} \mathrm{EXP}$ & 0.100168 & 0.015572 & 0.805869 \\
\hline$\sim \mathrm{FRI}^{*} \sim \mathrm{EF}^{*} \mathrm{IF}^{*} \mathrm{CHIL} * \mathrm{AGE}$ & 0.198373 & 0.010802 & 0.830787 \\
\hline
\end{tabular}

Solution coverage: 0.770763

Solution consistency: 0.721565

" " indicates absence of the condition and "*" indicates AND

Table 6 Intermediate solution for gender barriers

\begin{tabular}{|c|c|c|c|}
\hline Intermediate solution for gender barriers & Raw coverage & Unique coverage & Consistency \\
\hline $\mathrm{EF}^{*} \mathrm{CHIL}^{*} \sim \mathrm{AGE}^{*} \sim \mathrm{EXP}$ & 0.445406 & 0.020385 & 0.843024 \\
\hline$\sim \mathrm{EF}^{*} \mathrm{IF}^{*} \sim \mathrm{STA}^{*} \sim \mathrm{AGE}^{*} \sim \mathrm{EXP}$ & 0.074560 & 0.008378 & 0.873977 \\
\hline$\sim \mathrm{EF}^{*} \mathrm{IF}^{*} \sim \mathrm{STA}^{*} \mathrm{CHIL} * \sim \mathrm{EXP}$ & 0.075258 & 0.008378 & 0.816667 \\
\hline $\mathrm{FRI}^{*} \mathrm{EF}^{*} \sim \mathrm{IF}^{*} \mathrm{CHIL}^{*} \sim \mathrm{EXP}$ & 0.297263 & 0.024714 & 0.803700 \\
\hline $\mathrm{EF}^{*} \sim \mathrm{IF}^{*} \mathrm{STA}^{*} \mathrm{CHIL}^{*} \mathrm{AGE}$ & 0.249930 & 0.059481 & 0.791335 \\
\hline FRI*EF*IF*STA*CHIL & 0.284278 & 0.046216 & 0.759985 \\
\hline $\mathrm{EF}^{*} \mathrm{IF}^{*} \mathrm{CHIL} * \mathrm{AGE} * \mathrm{EXP}$ & 0.401983 & 0.031695 & 0.815350 \\
\hline $\mathrm{FRI}^{*} \sim \mathrm{IF}^{*} \sim \mathrm{FAM}^{*} \sim \mathrm{STA}^{*} \mathrm{CHIL}^{*} \mathrm{AGE}^{*} \mathrm{EXP}$ & 0.090059 & 0.009076 & 0.892116 \\
\hline $\mathrm{FRI}^{*} \mathrm{EF}^{*} \sim \mathrm{FAM} * \mathrm{CHIL}^{*} \mathrm{AGE}$ & 0.256911 & 0.000419 & 0.819964 \\
\hline$\sim \mathrm{FRI}^{*} \mathrm{EF}^{*} \mathrm{IF}^{*} \sim \mathrm{STA}^{*} \mathrm{CHIL} * \mathrm{EXP}$ & 0.106953 & 0.005306 & 0.802094 \\
\hline
\end{tabular}

Solution coverage: 0.733036

Solution consistency: 0.759329

“ " indicates absence of the condition and "*" indicates AND

The fsQCA method yielded three solutions: complex, parsimonious and intermediate. Here, we present the intermediate solution, which was calculated by including only the logical remainders that make theoretical sense (Tables 5 and 6).

In accordance with Woodside et al. (2013), solution consistency should be greater than 0.74 and solution coverage should be greater than 0.25 . The consistency of the intermediate solution for the training barriers is 0.72 , and consistency for the gender barriers is 0.76 . The coverages in both models are greater than 0.72 .

According to Ragin (2008) and Rihoux et al. (2009), the causal combinations with the highest values of raw coverage represent the strongest empirical evidence. Because the solution of training barriers is less than 0.74 , we focused on the gender barriers model. 
The causal conditions with the greatest raw coverages-thereby representing the strongest empirical evidence-are as follows:

\section{A. $\mathrm{EF}^{*} \mathrm{CHIL}^{*} \sim \mathrm{AGE}^{*} \sim \mathrm{EXP}$ \\ B. $\mathrm{EF} * \mathrm{IF} * \mathrm{CHIL} * \mathrm{AGE} * \mathrm{EXP}$}

The consistency of the solutions is 0.84 and 0.81 , respectively, so both values are greater than 0.75 and therefore meet Ragin's (2008) criterion.

The causal recipe (A) shows that difficulties in securing external financing facing young women entrepreneurs with children and a lack of expectations to expand contributes to gender barriers.

The causal recipe (B) shows that difficulties in obtaining financing (whether internal or external) together with having children in older female entrepreneurs contributes to gender barriers.

\section{Conclusions}

This study had two objectives. The first objective was to extend the literature on barriers faced by women entrepreneurs, and the second objective was to observe differences between results of the same analysis conducted using two statistical methodologies: one quantitative (PLS) and one qualitative (QCA).

All hypotheses were validated using PLS. Notably, however, in hypothesis 3, support from family and friends also presents a barrier to the creation of businesses by women. In this regard, some authors have established that women with greater independence achieve better results in their business activities. Given our results, it seems reasonable to think that women entrepreneurs are forced to achieve their business objectives with complete autonomy.

Regarding the fsQCA methodology, demographic characteristics of age, marital status and having small children are strongly related to the existence of both types of barriers. In addition, the combination of all three (age + marital status + children) is a necessary condition for the existence of gender barriers and education and training/infrastructure barriers. Furthermore, access to financing (i.e. internal or external) is also related to difficulties for women entrepreneurs. Finally, business expansion is not a necessary condition, but the combination of this characteristic with other conditions does form part of the gender barriers. Therefore, two of the hypotheses (H1 and H4) remain unconfirmed for education and training/infrastructure barriers, and $\mathrm{H} 4$ remains unconfirmed for gender barriers. The fsQCA method thus failed to find a relationship between the conditions studied and the barriers to women entrepreneurship.

Among the main conclusions in Akehurst et al. (2012) article we can find the following. Firstly, regarding financing, financial support to women affects the motivations and obstacles of her entrepreneurial venture. Secondly, as regards demographic factors, being single has a positive influence on ambition to becoming entrepreneur. Similarly, the age at which women found a firm affects both innate entrepreneurial attitude of the woman entrepreneur as well as the obstacles that she has to face and the success of the firm. Thirdly, female entrepreneurs that own bigger firms and firms that were founded with family loans have a higher success rate.

After performing the PLS analysis, we observe how almost all variables in the study are related to entrepreneurship barriers that women face upon creating their own business. This 
finding suggests that the PLS analysis is less restrictive as regards results than the regression analysis performed in the first study in 2012. On the other hand, regarding the QCA, combinations of variables under study can produce the expected outcome. Thus, three of the variables are necessary conditions to the existence of barriers to creation of business by women. Given that the objective is to find combinations of conditions that produce an outcome (or its absence), the variables observed individually are rendered insignificant.

Finally, this study is not extent from limitations that may offer some suggestions for future research. The results cannot be generalized because, as commented above, the region under study has its own specific characteristics. Future lines of research may include an interregional comparison. Furthermore, a complementary line of research could consist of incorporating other variables that the literature highlights, such as the analysis of the influence of the environment (Huarng et al. 2012) in which women start their activity as a conditioning factor of her entrepreneurship potential.

\section{References}

Akehurst, G., Simarro, E., Mas-Tur, A.: Women entrepreneurship in small service firms: motivations, barriers and performance. Serv. Ind. J. 32(15), 2489-2505 (2012)

Bang, Y.H., Yoo, C.K., Lee, I.B.: Nonlinear PLS modeling with fuzzy inference system. Chemometr. Intell. Lab. Syst. 64(2), 137-155 (2002)

Bang, R.D., Fang, M., Schwartz, S.C., Andress, K.M.: US Patent No. 5,715,325. US Patent and Trademark Office, Washington, DC (1998)

Barroso, C., Cepeda, G., \& Roldán, J.L.: Investigar en Economía de la Empresa: Partial Least Squares o modelos basados en la covarianza. In: Best Papers Proceedings (2005)

Bates, T.: Restricted access to markets characterizes women-owned businesses. J. Bus. Ventur. 17, 313-324 (2002)

Berg-schlosser, D.: Determinants of democratic successes and failures in Africa. Eur. J. Politi. Res. 47(3), 269-306 (2008)

Bruce, D.: Do husbands matter? Married women entering self-employment. Small Bus. Econ. 13, 317-329 (1999)

Brush, C.G.: Research on women business owners: past trends, a new perspective and future directions. Entrep. Theory Pract. 16(4), 5-30 (1992)

Brush, C.G., Duhaime, I.M., Gartner, W.B., Stewart, A., Katz, J.A., Hitt, M.A., Alvarez, S.A., Meyer, G.D., Venkataraman, S.: Doctoral education in the field of entrepreneurship. J. Manag. 29, 309-331 (2003)

Carter, S., Rosa, P.: The financing of male -and female- owned businesses. Entrep. Reg. Dev. 10, $225-241$ (1998)

Carter, S., Shaw, E., Lam, W., Wilson, F.: Gender, entrepreneurship, and bank lending: the criteria and processes used by bank loan officers in assessing applications. Entrep. Theory Pract. 31, 427-444 (2007)

Cepeda, G., \& Roldán, J.L.: Aplicando en la práctica la técnica PLS en la Administración de Empresas. In: Conocimiento y Competitividad. XIV Congreso Nacional ACEDE, pp. 74-8, Murcia (2004)

Chin, W.W., Marcolin, B.L., Newsted, P.R.: A partial least squares latent variable modeling approach for measuring interaction effects: results from a Monte Carlo simulation study and an electronic mail emotion/adoption study. Inf. Syst. Res. 14(2), 189-217 (2003)

Coleman, S.: Access to capital and terms of credit: a comparison of men and women-owned small business. J. Small Bus. Manag. 38(3), 37-51 (2000)

Cowling, M., Taylor, M.P.: Entrepreneurial women and men: two different species? Small Bus. Econ. 16, 167-175 (2001)

Crilly, D., Zollo, M., Hansen, M.T.: Faking it or muddling through? Understanding decoupling in response to stakeholder pressures. Acad. Manag. J. 55(6), 1429-1448 (2012)

Cronbach, L.J.: Coefficient alpha and the internal structure of tests. Psychometrika 16, 297-334 (1951)

DeMartino, R., Barbato, R.: Differences between women and men MBA entrepreneurs: exploring family flexibility and wealth creation as career motivators. J. Bus. Ventur. 18, 815-832 (2003) 
Du Rietz, A., Henrekson, M.: Testing the female underperformance hypothesis. Small Bus. Econ. 14, 1-10 (2000)

Eddleston, K.A., Powell, G.N.: The role of gender identity in explaining sex differences in business owners' career satisfier preferences. J. Bus. Ventur. 23(2), 244-256 (2008)

Fischer, E., Reuber, R., Dyke, L.: A theoretical overview and extension of research on sex, gender and entrepreneurship. J. Bus. Ventur. 8, 151-168 (1993)

Fiss, P.C.: A set-theoretic approach to organizational configurations. Acad. Manag. Rev. 32(4), 1180-1198 (2007)

Fiss, Peer C.: Building better causal theories: a fuzzy set approach to typologies in organization research. Acad. Manag. J. 54(2), 393-420 (2011)

Greckhamer, T., Misangyi, V.F., Elms, H., Lacey, R.: Using QCA in strategic management research: an examination of combinations of industry, corporate, and business unit effects. Organ. Res. Methods 11(4), 695-726 (2008)

Grofman, B., Schneider, C.Q.: An introduction to crisp set QCA, with a comparison to binary logistic regression. Political Res. Q. 62, 662-672 (2009)

Henningsson, M., Sundbom, E., Armelius, B.-Å., Erdberg, P.: PLS model building: a multivariate approach to personality test data. Scand. J. Psychol. 42, 399-409 (2001)

Hertz, N.: Women and Banks Are Female Customers Facing Discrimination. IRRP 2011. Institute for Public Policy Research, London (2011)

Herron, L., Robinson, R.: A structural model of the effects of entrepreneurial characteristics on venture performance. J. Bus. Ventur. 8, 281-294 (1993)

Hinz, C.: Women beyond the pale: marital "misfits and outcasts" among Japanese women entrepreneurs. Womeńs Stud. 33, 453-479 (2004)

Hisrich, R.D., Brush, C.G.: The Woman Entrepreneur: Implications of Family, Educational, and Occupational Experience. Frontiers of Entrepreneurship Research, pp. 255-270. Babson College, Wellesley (1983)

Huarng, K.H., Mas-Tur, A., Yu, T.H.K.: Factors affecting the success of women entrepreneurs. Int. Entrep. Manag. J. 8(4), 487-497 (2012)

Ianello, K.P.: Decisions Without Hierarchy: Feminist Interventions in Organization Theory and Practice. Routledge, New York (1993)

Kevane, M., Wydick, B.: Microenterprise lending to female entrepreneurs: sacrificing economic growth for poverty alleviation? World Dev. 29, 1225-1236 (2001)

Lerner, M., Almor, T.: Relationships among strategic capabilities and the performance of women-owned small ventures. J. Small Bus. Manag. 40, 109-125 (2002)

Morris, M.H., Miyasaki, N.N., Watters, C., Coombes, S.M.: The dilemma of growth: understanding venture size choices of women entrepreneurs. J. Small Bus. Manag. 44(2), 221-244 (2006)

Nunnally, J.: Psychometric Methods. McGraw, New York (1978)

Pellegrino, E.T., Reece, B.L.: Perceived formative and operational problems encountered by female entrepreneurs in retail and service firms. J. Small Bus. Manag. 20(2), 15-24 (1982)

Ogbor, J.O.: Mythicizing and reification in entrepreneurial discourse: ideology-critique of entrepreneurial studies. J. Manag. Stud. 37(5), 605-635 (2000)

Ordanini, A., Maglio, P.P.: Market orientation, internal process, and external network: a qualitative comparative analysis of decisional alternatives in new service development. Decis. Sci. 40(3), 601-625 (2009)

Ordanini, A., Parasuraman, A., Rubera, G.: When the recipe is more important than the ingredients a qualitative comparative analysis (QCA) of service innovation configurations. J. Serv. Res. 17, 1094670513513337 (2013)

Orhan, M.: Women business owners in France: the issue of financing discrimination. J. Small Bus. Manag. 39, 95-102 (2001)

Ragin, C.C.: The Comparative Method: Moving Beyond Qualitative and Quantitative Strategies. University of California Press, Berkeley (1987)

Ragin, Charles C.: Fuzzy-Set Social Science. University of Chicago Press, Chicago (2000)

Ragin, C.C.: Redesigning Social Inquiry: Fuzzy Sets and Beyond. University of Chicago Press, Chicago (2008)

Ragin, C.C., Davey, S.: fs/QCA [Computer Programme], version 2.5. University of California, Irvine, CA (2014)

Rey-Martí, A., Porcar, A.T., Mas-Tur, A.: Linking female entrepreneurs' motivation to business survival. J. Bus. Res. 68(4), 810-814 (2015)

Ribeiro, D.: Modeling the enterprising character of European firms. Eur. Bus. Rev. 15(1), 29-37 (2003a) 
Ribeiro, D.: Performance of innovative SME's. Revista Europea de Dirección y Economía de la Empresa 12(3), 119-132 (2003b)

Rihoux, B., Ragin, C.C.: Configurational Comparative Methods: Qualitative Comparative Analysis (QCA) and Related Techniques. Sage, Los Angeles (2009)

Ronsen, M.: Children and family: a barrier or an incentive to female self-employment in Norway? Int. Labour Rev. 153(2), 337-349 (2014)

Rosa, P., Carter, S., Hamilton, D.: Gender as a determinant of small business performance: insights from a British study. Small Bus. Econ. 8, 463-478 (1996)

Schneider, C.Q., Wagemann, C.: Set-Theoretic Methods for the Social Sciences. A Guide to Qualitative Comparative Analysis. Cambridge University Press, Cambridge (2012)

Schneider, M.R., Schulze-Bentrop, C., Paunescu, M.: Mapping the institutional capital of high-tech firms: a fuzzy-set analysis of capitalist variety and export performance. J. Int. Bus. Stud. 41(2), 246-266 (2010)

Steier, L.P., Chua, J.H., Chrisman, J.J.: Embeddedness perspectives of economic action within family firms. Entrep. Theory Pract. 33(6), 1157-1167 (2009)

Storey, D.: New firm growth and bank financing. Small Bus. Econ. 6, 139-150 (1994)

Sundbom, E.: Borderline Psychopathology and the Defense Mechanism Test. PhD Dissertation, Umeå University, Umeå (1992)

Umetrics, A. B. (2008). User guide to SIMCA-P+12

Verheul, I., Thurik, R.: Start-up capital: does gender matter? Small Bus. Manag. 16, 329-345 (2001)

Welsh, D.H., Memili, E., Kaciak, E., Ochi, M.: Japanese women entrepreneurs: implications for family firms. J. Small Bus. Manag. 52(2), 286-305 (2014)

Wold, H.: Model Construction and Evaluation when Theoretical Knowledge Is Scarce: An Example of the Use of Partial Least Squares. Cahiers du Département D́Économétrie. Faculté des Sciences Économiques et Sociales, Université de Genève, Genève (1979)

Wold, S., Albano, C., Dunn, W.J., Esbensen, K., Hellberg, S., Johansson, E., et al.: Pattern recognition: finding and using regularities in multivariate data. In: Martens, H., Russworm, H. (eds.) Food Research and Data Analysis. Applied Science Publishers, London (1983)

Woodside, A.G., Zhang, M.: Cultural diversity and marketing transactions: are market integration, large community size, and world religions necessary for fairness in ephemeral exchanges? Psychol. Mark. 30(3), 263-276 (2013)

Yilmaz, E., Oraman, Y.: Women entrepreneurs: their problems and entrepreneurial ideas. Afr. J. Bus. Manag. 6(26), 7896-7904 (2012) 